\title{
Ethno-territorial Protest Movements and the Politics of Accommodation in Centralized and Decentralized Political Systems \\ Christian Lammert
}

\begin{abstract}
The main purpose of the paper is to explain the divergent paths of development of ethno-territorial protest movements in modern democratic political systems. By focusing on the interaction between these movements and the state, the different systems of accommodation between the relevant regional and central elites will be analyzed. The study concentrates on the case studies of Québec (Canada) and Corsica (France). The paper is divided into three parts. The first part describes the traditional systems of accommodation in France and Canada. The second part is focused on the process of socio-economic modernization in the 1950s and 1960s in those countries that threatened the established patterns of elite accommodation. The third part deals with the consequences for the established patterns of elite-accommodation and new concepts of territorial management that the central states tried to establish. By looking at the different degrees of centralization and decentralization in the mentioned political systems, the question of access to the political system by new social and political actors will be discussed in detail.
\end{abstract}

\section{$\underline{\text { Introduction }}$}

At least since the early 1960s ethno-territorial protest movements have increasingly challenged established patterns of political integration in western democracies. Great Britain, France, Spain or Canada, to name just a few examples, have all experienced such challenges. But it is not just the governments of these states who have to deal with this problem. It also poses a challenge to the social sciences, which have to explain the formation of these movements, and must also investigate the causes of the different paths of evolution the movements have taken. With regard to the latter aspect, and especially the nationalist movements in Corsica and Québec, we are presented with starkly dissimilar cases of conflict evolution. In the case of Corsica we can clearly

Christian Lammert, "Ethno-territorial Protest Movements and the Politics of Accommodation in Centralized and Decentralized Political Systems." Federal Governance: A Graduate Journal of Theory and Politics. 1:2 (2003)<http://cnfs.queensu.ca/federalgovernance/index.html> 
speak of a progressive radicalization of nationalist activities and a fragmentation of the nationalist movement, with some of the groups operating outside the legal bounds of the political system. ${ }^{1}$ The first signs of regional conflict articulation in Corsica became visible in the late $1950 \mathrm{~s}$, and can be described as a reaction against the central state policy of regional modernization in France. ${ }^{2}$ The subsequent radicalization of the movement can be described in different phases, and can be explained as a result of the interaction of the regional protest articulation and the response of the French state. ${ }^{3}$ High rates of terrorist activities and the participation of a variety of nationalist parties in the political system of Corsica are manifestations of this radicalization. Taking a different path, the nationalist movement in Québec has become highly integrated into the political system of the mainly francophone province, threatening the cohesion of the Canadian federation from inside the constitutional framework. In contrast to the fragmented Corsican movement, the nationalist forces in Québec are, at least since the founding of the Parti Québécois in 1970, for the most part integrated into this party. This party has shown a high degree of internal coherence over the last 30 years. ${ }^{4}$ Two legal referendums for independence in 1980 and 1995, and a strictly nationalist politics of the PQ in government, are the visible signs of the integration of the nationalist forces into the political system.

The purpose of this paper is to take a closer look at the factors and conditions of the different paths of conflict evolution. The argument is developed in three stages. First, a theoretical framework is developed that focuses on the concept of elite interaction as a pivotal factor for the evolution of nationalist movements. Second, traditional patterns of elite accommodation before the upsurge of regional and nationalist protest in Quebec and 
Corsica are discussed, and the factors that threatened these systems are analyzed. Third, the evolution of the movements and the response of the respective states from the $1960 \mathrm{~s}$ until today are investigated.

\section{Theoretical Framework}

The (re)emergence of ethno-territorial protest movements in the 1960s has lead to a lively discussion in the social sciences. Until the mid 1960s, ethno-nationalism and ethno-nationalist movements had been largely ignored. Modernization theories treated ethnicity as a somewhat archaic phenomenon, which was alleged to disappear in the process of modernization. ${ }^{5}$ The political, social and economic conditions of modernization, it was assumed, required increasing standardization and homogenization. The main agents of change were to be the educational system and the media, along with the army. Additionally, national elites were to transform the culturally different parts of the population into one political community, sharing historical symbols, descent and national interests, regardless of social inequalities and class differences. ${ }^{6}$

With the benefit of hindsight, it is safe to conclude that modernization did not work as smoothly or uniformly as these theoretical models suggested. The persistence and reemergence of ethno-territorial protest movements posed a challenge that could hardly be ignored. At first, the attempts to cope with these perplexing anomalies tried to incorporate regional protest into the framework of modernization theory. Arend Lijphart, in particular, approached the problem as part of the nation-building process itself: if the latter is advancing too fast, the danger of a defective form of integration and assimilation of some groups arises. Lijphart still presupposed the integrative effects of modernization, 
but saw a disturbed transaction-integration balance as a base for ethnic conflicts. Lijphart wrote:

In the first place modernization may have assimilative effects in the earlier stage of the development but not in later stages....Second, national assimilation is an extremely slow process. This means that social mobilization is conductive to assimilation but only up to a certain point: when mobilization is rapid, assimilation will lag behind. ${ }^{7}$

A second type of approach has focused on the relationship between national minority movements and the process of socio-economic modernization. This approach depicts ethnic identities in opposition to the inescapable processes of modernization, as a revolt against modernity. As Seymour Lipset has written in this regard:

The most dramatic form of resistance to modernizing trends in post-industrial society has been the re-emergence of ethnic or linguistic nationalism in many countries. These movements object to the centralization of power, economic strength, and cultural dominance in the majority regions of their country. They seek, either through gaining independence or autonomy, to control educational and cultural facilities and to build up the economy of their areas. ${ }^{8}$

In this context ethnic identity is seen as a given, primordialist concept and defined as a counterweight to socio-economic modernization. Ethnicity, in effect, is conceptualized as a basic principle of social reality that sleeps under the surface of modern societies and that is awakened if modernization fails.

A third type of approach assumes a closer connection between the process of modernization and the emergence of ethno-territorial protest movements. Studies from this perspective focus mainly on the connection between the historical roots of identities and the current form of identity articulation. The objective is to better understand the conditions that will lead to a politicization of ethnic groups. As in the primordialist approaches, ethnic identities are conceptualized as a given factor. But in contrast to the 
former the emphasis is on the causal factors that breed dissatisfaction and finally result in a rejection of established patterns of political integration. The conditions seen as the driving forces vary substantially in different models: in some cases uneven economic development is viewed as the main cause of mobilization. ${ }^{9}$ More generally, the cause is sometimes seen as simply the perception that a group or territory suffers from an unequal distribution or resources. ${ }^{10}$ Michael Hechter, for example, speaks of the cultural division of labour as the main source of ethnic conflict, ${ }^{11}$ whereas other authors explain regional protest with reference to sectoral differences in the process of modernization. ${ }^{12}$ Yet all approaches share the assumption that the key factors are part of the socio-economic situation of the analyzed group or territory as compared to the dominant society or to the core region of the state. Differences in economic growth rates, and in the pattern of political integration, result in a perception of inequality that can be interpreted in a cultural, political or economic sense. ${ }^{13}$

But, as I have mentioned earlier, there are significant differences in the evolution of the nationalist movements in Corsica and France. Despite similar socio-economic environments the patterns of conflict evolution differ markedly in these two cases. This, I would argue, can neither be explained with reference to factors relating to the movement themselves nor with reference to differences in the center-periphery structure. We need to reach beyond the factors discussed above and, in particular, introduce a temporal dimension into the comparative framework. The approach presented in this paper is designed to take into consideration the interests, goals and priorities of the nationalist movements as well as the response of central state powers from this perspective. It attempts to link different approaches and to focus on the often-neglected interaction of 
the policies of ethno-territorial movements and the central governments as they unfold over recurring feedback cycles.

This approach is closer to the conceptual viewpoint of Paul Brass, who interprets ethnic identity as well as modern nationalism in large parts as a result of the interaction between the political elites of the central state and the elites of the respective nondominant ethnic groups, as determined by political and economic factors. Cultural norms and values of ethnic groups become political resources in the conflict for political power and economic advantages. ${ }^{14}$ For Brass:

\footnotetext{
Ethnic communities are created and transformed by particular elites in modernizing and in post-industrial societies undergoing dramatic social change. The process invariably involves competition and conflict for political power, economic benefits, and social status between competing elite, class, and leadership both within and among different ethnic categories. ${ }^{15}$
}

The main question is concerned with the conditions of the conversion of cultural differences into a basis for political differentiation. The historical dimension of this evolution has to be taken into consideration. Central elements of this argument are, in particular, the traditional alliances between the respective elites who, in combination with the established institutional decision structures, set the framework for political action of the central elites vis-à-vis the ethno-territorial protest movement.

This theoretical approach seems to be open enough to account for the mentioned deviations in the evolution of the movements in Corsica and Québec, and may also help to explain why both movements did not come into existence before the 1960 s. What kind of systems of elite accommodation guaranteed a stable political order before the 1960s, and what are the causes of the crisis of these successful systems in Canada and France? 
To answer these questions this paper analyses the patterns of elite accommodation until the 1960 s and the process of socio-economic modernization in both countries, and their consequences for the elite accommodation. The second part of the paper deals with the newly established political, economic, and societal elites and the following structures of elite accommodation in Canada and France. What happened to the old elites and how could the new elites integrate into the existing political orders?

The interaction of political elites and the process of accommodation depend highly on the established structures and institutions of interest accommodation. Especially France and Canada, with their totally different models of political organization, might clarify the significance of political structures and institutions for the evolution of nationalist movements. The federal Canadian system, which is based on the concept of different cultures being integrated into one political system, provides many forms and places for political participation. In opposition to this model, the unitary and highly centralized French model ignores the existence of cultural and ethnic minorities, and is based on the ideology of the one and indivisible French republic. This model is relatively closed to the articulation of newly formed political, social and economic interests. Such an approach allows us to distinguish clearly between the confining institutional, socio-economic and cultural conditions that constitutes the room for political action on the one side, and those factors on the other side that trace back to the motivations and decisions of political actors within this room. Tarrow's concept of political opportunity-structure, which has be refined by Rokkan and Urwin, might also be a helpful instrument to gauge the involved groups potentials for political action and the respective limits on their potentials. ${ }^{16}$ Tarrow is focused on three factors: the openness or 
closeness of the political system for the articulation of new and alternative political interests, the stability of the electorate and the disposability of political partners in the system. The factors can by investigated by an analysis of the established forms of regional interest integration into the national system.

\section{$\underline{\text { Traditional Patterns of Elite Accommodation }}$}

If we follow Paul Brass in explaining the formation of ethno-territorial protest movements as, at least in part, a result of elite interaction, we have to explain why a nationalist uprising in Corsica or Québec did not follow the interaction of the elites prior to the 1960s. Were there comparable structures of elite accommodation in France and Canada that guaranteed stability over such a long period? In both cases we can clearly speak of a stable political structure that had been based on the established systems of elite accommodation in each country. But the two models of elite accommodation show different institutional characteristics. In Corsica we can speak of an informal system of elite accommodation that provides new political actors just few opportunities for participation. Besides the highly centralized center-periphery structure in France that is built on the system of prefects at the departmental and local level, there are influential local elites that were able to effectively secure their integration at the beginning of the state-building process in France. Because of language problems and different cultural traditions in the regions that had to be integrated into the French state, national elites needed help from locally influential elites to pursue the politics of nation- and statebuilding in France. These local elites - named notables in France generally or clans in Corsica - attained a position as nation-building-helpers in the center-periphery structure and were thus able to maintain their local power position despite the centralizing 
tendency of the French state and integrated well into the newly formed center-periphery structure in France. ${ }^{17}$ Jack Hayward explains:

Without such concessions to the countervailing power of the local communities, the strict interpretation of the rules would shatter the semblance of national unity which is the shibboleth on which state authority is based. ${ }^{18}$

The notables were able to enlarge their power position in the local community, because the political elites of the central state needed their cooperation to fulfill the process of nation building. This pouvoir périphérique ${ }^{19}$ and the institutional centralism are the essential elements of a reciprocal system of cooperation that overruled the vertical construction of the established institutions. Local elites and the representatives of the central state operated in a framework of a more informal decision structure. A parallel and relatively autonomous decision making process was a consequence of this constellation of political actors.

Though the relatively rigid center-periphery-structure included local notables and the prefects as key figures in the system of local government, and the informal channels of communication between the different levels of government assured the integration of regional interests in Paris, this arrangement made the articulation of alternative political interests difficult. As long as the notables were able to stabilize their positions, this system of elite accommodation guaranteed a stable center-periphery-structure between Corsica and Paris.

In comparison, the system of accommodation in Québec bears a higher degree of institutionalization than the case of Corsica. This implies that there is more room for political action on the sub-national level, and that political actors have a lot of resources 
for political decisions. This center-periphery structure has therefore been more open for new political actors, at least if we compare it with the Corsican case. The system of elite accommodation in Corsica is characterized by the cooperation of the notables with the French state in which and the notables try to prohibit the formulation of alternative political interests. The system of accommodation in Québec on the other hand is based on the principle of non-interference, i.e. the political powers are strictly separated between the different levels of government, the provincial and the national. This arrangement in Québec is the result of a historical evolution that started long before the formation of the Canadian federation in $1867 .^{20}$

As a result of the process of socio-economic modernization, both systems of elite accommodation came under pressure after the Second World War. The processes of modernization, both in the socio-economic and in the political dimension, affected the established systems of elite accommodation in Québec and Corsica in different ways. The system of elite accommodation in Corsica proved to be highly adaptable to the process of modernization and helped to soften the impact of this process on the Corsican population. Developments in Québec took a different path. The process of modernization had a serious impact on the political system and the established institutions and actors. Traditional elites in Québec, the clergy and the traditional nationalists, organized in the Union Nationale of Duplessis, were not able to adapt to the new socio-economic situation and new forces, classes and actors assumed their position in the Québecois society. This process is known as the Quiet Revolution.

Traditional local elites in Corsica benefited from the process of modernization and were able to stabilize their position in the Corsican society. These divergences are to a 
large degree the result of the different systems of elite accommodation in the both cases.

The center-periphery structure in Corsica — based on informal but rigid channels between the local and the national system-- assured local elites, i.e. the notables, access to the necessary resources — jobs in the administration and public money — to consolidate their pivotal position between the local society and the French state. Furthermore, they were able to strengthen their position, both because of their adaptability to the new circumstances, and because the center- periphery structure was closed to the formation of new political interests, articulated by the so-called new middle classes. Traditional elites in Québec, on the other hand, were incapable of readjusting to the new realties of the modern welfare state that was built in Canada after the Second World War. The patterns of the relationship between the different levels of government in Canada that granted local political actors a great degree of freedom in articulating their interests on the subnational level allowed the integration of the new economic and political interests of the new middle class into the institutions and the system of interest representation of the political system. Additionally Corsica missed the formation of a relevant political counter elite and the building of a strong working class like Québec that could have imperiled the strong position of the notables.

Analyzing the formation of nationalist movements in this way, as I have mentioned before, is very close to the approach of Paul Brass. Brass defines eliteconcurrence as the main factor in the conversion of cultural differences into a basis of political difference. Naturally some conditions have to be met, but these conditions are primarily political or economic in character rather than cultural. In this perspective, ethnic identity or shared cultural or ethnic backgrounds are seen as flexible resources in 
the political statement of diverse political interests on the sub-national as well as on the national level. The analyzed cases, Corsica and Québec, clearly indicate how different political actors on the sub-national level compete with the same concepts of ethnic identity for the electorate. Cultural values and practices become political assets in the quarrel for political power and economic advantages.

\section{$\underline{\text { New Models of Elite Accommodation in France and Canada }}$}

The process of socio-economic modernization, particularly after World War Two, had different effects on the respective established traditional systems of elite accommodation, as was shown above. The new social forces, coming first of all from the recently formed new middle classes that formed the basis for the nationalistic interest articulation during the 1960s, were confronted with different institutional and structural conditions in Corsica and Québec that considerably influenced their further development. In the following, I will discuss the evolution of the both movements and work out the conditions for the deviating paths of evolution they took by using Brass' concept of elite concurrence.

I will proceed by discussing Corsican nationalist movement first, proposing the following classification of the three step-development: The first phase, which I will refer to as the phase of economic regionalism, lasts from 1957 to 1970 . The second phase, from 1970 to 1975 , will be labeled autonomistic regionalism and the last and third, from 1975 to present, may be termed nationalistic regionalism. In general, two questions or sets of questions will guide my analysis: First, what causes the protest, and second, how can we explain its progressive radicalization? As a preview of the core argument, the 
three main propositions are as follows. First, the formation of the nationalist movement in Corsica is closely linked to French regional planning policies in the Post-Second World War era. Second, the movement that formed in this period must be clearly distinguished from older nationalistic movements in Corsica. Third, the radicalization of the movement can be explained mainly be the rejection of the French government to cooperate with moderate forces in Corsica.

The first protest groups in Corsica were organized in the late 1950s as a direct response to the regional action program of the French government initiated in 1957. The program's goal was to alleviate the consequences of socio-economic modernization in Corsica. The main group was named Centre d'études régionales Corse. It was a primarily economically oriented group and its leadership followed a cooperative strategy towards the French government that was designed to help the French government in the implementation of the regional action program. ${ }^{21}$ This type of groups still constitutes one major strand of the nationalist movement.

At nearly the same time, Corsican students on the French mainland began to organize in student groups (Union Corse, Union national d'éstudiante corse), the core organizations of the second strand of Corsican nationalism. These groups were strongly influenced by socialist ideologies and the process of decolonization. ${ }^{22}$ In 1966 the biggest two student organizations combined into the Front Régionaliste Corse (FRC). From the perspective of this more radical and culturally oriented strand of the nascent nationalist movement the situation of Corsica was interpreted as a part of the general decolonization process. 
In the mid 1960s the so called forces vives in Corsica - vendors and petty bourgeois were organizing the Comité d'études et de defense des interets de la Corse (CEDIC) ${ }^{23}$ As in the case of the aforementioned Corsican Center for Regional Studies, the CEDIC represents the cooperative strand, whose primary function is to articulate economic interests. 1967 the FRC and the CEDIC merged into the Action Régionaliste Corse (ARC). But because of different interpretations of the causes of the Corsican problems the movement split only one year later into ARC and FRC. Here the ARC represents the moderate wing with, again, a primarily economic outlook. In the 1970s, though, the moderates added a new element to their program: the concept of autonomy. The concept of internal autonomy had already been discussed in the 1960s, but had not been a key element of the movement in explaining the political priorities of economic modernization and the displacement of the indigenous Corsican economy as an objective and consequence of the French politics of decolonialization. ${ }^{24}$

With the adoption of 'internal autonomy' as a key political demand, the second phase of the evolution of the ethno-territorial movement begins: Corsican autonomism. In spite of generally rising tensions, different degrees of radicalization still characterized the various parts of the movement at this stage, with the radical and socialistic strand represented in the FRC and a moderate and pragmatic strand represented by the ARC. But a second regional action plan proposed by the French government clearly strengthened the radical wing. The new plan followed a narrow logic of economic efficiency and envisioned an enlargement of the tourism and agricultural sector on the island. Critical reports predicted a one-sided and, in the long run, catastrophic development of the Corsican economy as the likely consequence of the regional plan's 
implementation. The French governments indifference towards Corsica's main economic problems seemed to validate the radical view and helped to further the radicalization of nationalist rhetoric as well as group activities.

In the mid 1970s the French government began to react to the ethno-territorial movement in Corsica by banning the ARC. The event that provoked the French government's drastic reaction was the so-called Aleria affair. In 1975 the ARC seized a vineyard in Aleria to protest against a wine scandal. The French state interpreted this public relations stunt as an immediate threat to French national unity and ended the occupation with massive military and police forces. The ban of the ARC and the generally more repressive posture of the French government lead to a further radicalization, and drove parts of the movement underground.

From this perspective the Aleria affair can be seen as a turning point that demarcates the beginning of the third and final stage in the Corsican movement's development: the phase of separatism. To name just two of the more prominent organizations of the nationalist movement after 1975: The Fronte de la Liberation Nationale de la Corse (FLNC) is an example of an illegal group, later breaking up into several new groups, among them the canal historique and the canal habituell. The successor of the forbidden ARC, the Union di u Populu Corsu (UPC), presents an example of a legal group, working within the Corsican political system and regularly winning about 8 to 10 percent of the popular vote in regional elections. ${ }^{25}$

Whether analyzing the general trend or individual incidents, the historical sketch of the conflict between the nationalist movement and the French government since the 
late 1950s suggests a clearly defined pattern of continuous escalation. First the French government ignores the grievances and demands articulated by the Corsican movement, and then reacts to the resulting radicalization in a way that deepens the rift between the government and the groups. Viewed from a slightly different angle, this spiral of escalation, based on the particular mode of interaction between the two sides, drives and explains the progressive radicalization in Corsica.

While the strategy and policy on the part of the French government are a vital factor, two other aspects need to be taken into consideration. Both work to limit the ability of the Corsican movement to mobilize support: on the one hand the peculiarities of the Corsican political system, on the other the French socialist party's reform program.

With respect to the power structure of Mediterranean island, the clan system is a key element whose importance can hardly be overstated. For generations a few families have controlled the island. The French state has become dependent on this local elite, bringing it into the role of a mediator or a broker between the state and the Corsican community. The clan system has proved to be extremely adaptive in the process of socioeconomic modernization and political reforms implemented as part of the French policies of decentralization and regionalization. The devolution French-style has stabilized the power position of the clans and prevented the new forces-vives from fully participating in the political process.

Secondly, the socialist policy of decentralization brought Corsica a statute particulier (1982) with special rights and powers. The reform has sharply curtailed the political potential for nationalist mobilization on the island. The statute particulier offers 
the Mediterranean island special treatment well beyond the concessions associated with the politics of decentralization. For example, Corsica is the first French region that has been reorganized as a regional corporation, not merely an administrative unit, but a political entity with certain independent functions and powers. The electoral system has been reorganized to strengthen the smaller parties. The regional council of Corsica has been renamed 'National Assembly' and, going further than institutional reforms in other French regions, a council for culture, education and quality of life has been instituted.

Measured against its objectives, the statute particulier has failed. One reason was that it was not implemented in a dialogue with Corsican political elites. Thus autonomists as well as separatists rejected it. The clans also rejected the proposed reforms, but have been able to take advantage of the reform, again strengthening their power position. As a consequence, the intended integration of the ethno-territorial protest movement, or at least major parts of it, has not been achieved. As with earlier reform programs, the statute particulier fell short of the expectations of the nationalist movement. In the following decade the French socialists gave up on the policy of dialogue with the movement, returning to a tougher, less cooperative approach.

Since the mid 1980s the pattern of interaction between the French state and the Corsican movement has remained unchanged. The situation has been complicated considerably by the underground groups' cooperation with organized crime. This cooperation is rejected by a vast majority of the Corsican population and has discredited the whole national movement. 
Whereas newly formed groups first articulated regional protest in Corsica, protest in Quebec found expression within the established political system from the outset, the main and most important agent being the Parti Liberal du Québec (PLQ). ${ }^{26}$ Thus 1960 , the year the PLQ took power from the Union Nationale, seems to be the obvious date to set as the beginning of the evolution of the modern nationalist movement in Quebec. 1960 is also a year discussed in the literature as the starting point of the Quiet Revolution. The programmatic transformation of the PLQ comes into sharper focus when viewed against the background of its traditional anti-nationalistic outlook. Until the 1950s the PLQ had been nothing more than a regional chapter of Liberal Party of Canada. The PLQ had been concerned mostly with policies on the federal level and the party had tried to articulate francophone interests as a part of this strategy. But tensions rose between the growing party bureaucracies at the provincial and the federal level. In combination with the increasing importance of provincial institutions resulting from the build-up of the Canadian welfare state, these tensions lead to a growing independence of the Liberal Party chapter in Quebec. ${ }^{27}$ The process of socio-economic modernization in Canada also resulted in a fragmentation of the political system and the party system, primarily between the federal and provincial level. The centrifugal tendencies were particularly strong in the case of the francophone province that enjoyed a special status guaranteed by the Québec Act of 1774. Until the 1960s the established model of elite accommodation between the federal state and the francophone province had worked well. But this system of power sharing in Quebec was not adequate to the need of the modern welfare state. A new middle class found its way into the PLQ, using it as the main vehicle for its integration into the political system. ${ }^{28}$ 
The growing significance of provincial institutions and their power in the Canadian federation lead to rising tensions in the PLQ. As a consequence René Lévesque left the party in 1968 and founded the Movement Association Souverainité and, later, the Parti Québécois (PQ). The PQ gained 23.1 percent of the votes in the election of 1971, won the provincial election of 1976, and was thus able to establish itself as a relevant actor.

Since the 1970s, the PQ has been a constant and strong factor in provincial and national politics. ${ }^{29}$ In the early phase we can distinguish two wings of the PQ: a radical wing that opted for immediate separation of the province from Canada, and a moderate wing that demanded a referendum on the question of separation to be held before deciding on the future of the province. The latter gained control over the party and the election of 1976 was won with other issues than separation. Until the 1980s the concept of separation did not figure prominently in the program of the PQ. It is hard to take the first referendum in 1980 as a clear indicator for wider support for independence. The referendum question was phrased in a way that implied no real independence from the Canadian federation, but a complex arrangement of sovereignty association: a kind of part-time separation, with many responsibilities left to be shared with the Canadian federation. ${ }^{30}$ A closer look at public opinion surveys indicates no support for separation beyond the proposed 'soft solution'. A clear-cut secession from the Canadian federation was rejected by most of Quebec's voters. ${ }^{31}$ Thus after the failure of the referendum in 1980 the question of separation was pushed off the PQ's political agenda. Only under the new leadership of Jacques Parizeau, in 1989, did the PQ reorient its programmatic course towards separation. Interestingly, this move was not followed by an increased support 
among voters. In the mid-1990s separation was again on the agenda of Quebec politics. In the second referendum on separation in 1995 a razor-thin majority of 50.5 percent voted against separation. But as in the referendum 1980, the watered-down wording of the referendum question makes it hard to speak of a referendum on separation. In case of adoption, the referendum would have given the Quebec government nothing more but a mandate to negotiate a reform of the Canadian federation with the federal government. The legal process of separation was in no way discussed. ${ }^{32}$

Thus the presence and strength of the PQ in the provincial political system cannot be taken as an indicator of the support for independence in Quebec. The party has presented itself as a political alternative to separation. With a partly social democratic and partly conservative program the PQ has tried to distinguish itself from the PLQ. So how can we measure support for independence in Quebec in other ways than by using PQ vote shares? A look at voter surveys can help us in this regard. On the basis of survey data we can identify waves of nationalistic mobilization in Quebec: an increase toward the end of the 1970s, peaking at the time of the referendum in 1980. After the repatriation of the Canadian constitution in 1982 a decline until the early 1990s, then again an increase leading up to the second referendum in 1995. Since the second referendum the support for independence has fallen off again. ${ }^{33}$

\section{$\underline{\text { Conclusion }}$}

To sum up the argument, the consequences of the process of socio-economic modernization vary in accordance to the character of the established system of elite accommodation. The differing dynamics of evolution of the nationalist movements in 
Corsica and Québec is mainly a result of the position of the nationalist movement in the political system. This is conditioned by the established political institutions and the framework for political action for the relevant actors that follows from them. The relevant actors are the agents of the nationalist movement themselves, as well as the competing political elites on the sub-national level and the state as representative of the subordinated political power. In both cases, Corsica and Québec, there is an immanent radicalization of the ethno-territorial protest movement that can be seen in different phases of development. At the beginning of this evolution the protest articulation of the movement is primarily motivated by economic aspects and concerned with the outcome of the process of socio-economic modernization on the sub-national level. In a second step, the focus is complemented by a cultural interpretation of the economic malaise. Concepts of autonomy increasingly gain the attention of the leaders of the nationalist movement. In a last step of radicalization the antagonism between the movement and the state becomes greater and some parts of the movement propose to separate from the existing political system and form a new state.

This radicalization is mainly the result of the interaction between the movement and the state. In a first step the state ignores the demands of the ethno-territorial protest movements. This is followed by a radicalization of the nationalist movement with respect to their goals and their approaches. This in turn is followed by concessions of the state authorities that however lags far behind the new demands of the movement. This interaction-escalation spiral can be seen in the French discussion about the politics of decentralization and regionalization as well as in the Canadian constitutional discussion. But the outcome of this spiral differs significantly in regard to the organization of the 
nationalist movement between Corsica and Québec. The nationalist movement in Québec was able to integrate into the political system in the form of the Parti Québecois, whereas the integration of the nationalist movement succeeded only partly and some parts of the movement are fighting outside the legal bounds of the constitution for an independent Corsica.

As we show above, this is primarily a result of the different systems of interest integration and different types of center-periphery structures in both countries. The rigid structure in France that functions in the Corsican case, with the clans as mediators between the island society and the state, proved to be adaptable to the process of modernization following the Second World War. The Corsican protest movement that later on built the base of the nationalist movement was not integrated into the political system and had to look for other ways of interest articulation. The socialist regional reforms of the 1980s guaranteed a more successful integration of the nationalistic forces, but the radicalization of the movement had already happened in the 1970s as a result of the clan dominance and the established models of elite accommodation on the island. Furthermore the fragmentation of the nationalist movement in the 1970 s weakened the legal strands of the movement. Violence and organized crime have de-legitimized the ethno-territorial movement in the Corsican society. Beyond this the strong French state and the strong French ideology of 'the one and indivisible republic' have further weakened nationalism in Corsica.

The specific patterns of the center periphery structure between Corsica and the French state assure autonomous political spheres for the local elites in Corsica, but these 
spheres have never been organized in democratic institutionalized structures. This would have been contrary to the interest of the notables, as the informal system of elite accommodation stabilized their position and fenced off alternative political forces.

The situation in Québec presents a different picture. The new political forces that were organized in the process of socio-economic modernization were able to integrate themselves into the political system of the mainly francophone province Québec. This is partly because of the openness of Canadian federalism and the substantial degree of autonomy that allows regional and local actors to play an important role in the decision making process. In particular, the distinct situation of the province of Québec has to be mentioned here. The historically contingent, asymmetrical structures and elements of Canadian federalism left enough room for the nationalists in competing for votes and power.

To conclude, it seems clear now that support for and the success of nationalist arguments and movements is to a great extent the product of the political system itself. We can observe this mechanism also in the Western Canadian provinces, where a subnational identity has been built without common cultural or ethnic tradition. It is obviously clear that this mechanism applies especially to the movement in Québec that is based on a set of common cultural norms and traditions and institutionalized rights on distinctiveness. The governing elites on the sub national level are influencing the evolution of the national movements with their political decisions and policy instruments. These policies do not have to be based on cultural or ethnic traditions to have this impact on the evolution of the national movement. ${ }^{34}$ In a federal system like Canada, the 
influence of these factors is bigger than in a centralized system like France, because the framework for political action is wider and more institutionalized on the sub-national level. In France, the center-periphery structure is primarily based on an informal system of interest accommodation. The provincial political elites in Canada want to protect the longstanding interests of their society and economy; they also they have a vested interest in provincial status and power which the several provincial electorates do not share fully, ${ }^{35}$ which means an interest in maintaining political and administrative power themselves. These interests exist on the national level as well. The provincial as well as the national governments are not neutral contenders or reflecting mirrors, but aggressive actors steadily extending their tentacles of control, regulation, and manipulation into society_playing, in Deutsch's 'terminology, a steering role - and thus fostering sets of integrated relationships between themselves and the various socio-economic forces and interests in their jurisdiction. ${ }^{36}$

Alain Cairn's argument is very similar to the argument outlined in the work of Paul Brass. Following Brass, ethnic identity originates from the specific interaction between the elites of the central state and the elites of non-dominant ethnic groups. ${ }^{37}$ It is not just the existence of cultural differences that is important, but the way in which these differences are converted into a basis for political differentiation. The central state response to the regional protest articulation plays an important role in shaping the problem. The established institutional framework and the process of interaction inbetween this framework determines the evolution of nationalist movements more than cultural factors. 


\section{$\underline{\text { Notes }}$}

${ }^{1}$ For the current evolution of the nationalist movement in Corsica, see Pierre Poggioli, Corse: Chronique d'une Ile Déchirée (Paris: L'Harmattan, 1999), and Isidre Molas, "Partis Nationalistes, Autonomie et Clans en Corse", WP núm. 181, (Institut de Ciènces Polítiques i Sociales: Barcelona, 2001).

${ }^{2}$ For the French politics of decentralization and regionalization, see Vivian Schmidt, Democratizing France. The Political and Administrative History of Decentralization, (Cambridge: Cambridge Univ. Press, 1990).

${ }^{3}$ Christian Lammert, "Nationalist Movements and the State in Canada and France. Ethno-territorial Protest Movements in Québec and Corsica, 1960 to 1995", Zeitschrift für Kanada-Studien 21, 2 (2001), forthcoming.

${ }^{4}$ For a detailed analysis of the nationalist movement in Québec, see Kenneth McRoberts, Quebec: Social Change and Political Crisis (Toronto: Univ. of Toronto Press, 1988); Kenneth McRoberts, Misconceiving Canada: The Struggle for National Unity, (Toronto: Oxford Uni. Press, 1997); John Fitzmaurice, Quebec and Canada: Past, Present and Future (London: C. Hurst \& Co., 1985); and William D. Coleman, The Independence Movement in Québec, 1945-1980 (Toronto: Uni. of Toronto Press, 1984).

${ }^{5}$ For the theoretical approach, see K.W. Deutsch, Nationalism and Social Communication (Cambridge: MIT Press, 1966). For an empirical investigation of the French process of nation building, see Eugene Weber, Peasants into Frenchmen. The Modernization of Rural France, 1870-1914 (London: Chatto \& Windus, 1977).

${ }^{6}$ Benedict Anderson, Imagined Communities: Reflections on the Origin and Spread of Nationalism, (London: New Left Books, 1983); Eric Hobsbawm, Nations and Nationalism since 1990 (Cambridge: Cambridge Uni. Press, 1990).

${ }^{7}$ Arend Lijphart, "Political Theories and the Explanation of Ethnic Conflict in the Western World", in Ethnic Conflict in the Western World, ed. Milton Esman (Ithaca: Cornell Univ. Press, 1977), p.46-64, p. 48f.

${ }^{8}$ Seymour Lipset, The Revolt Against Modernity", Mobilisation, Center-PeripheryStructure and Nation-Building, ed. P. Torsvik (Bergen: Univ.-Forl., 1981), p.451-500, 472.

9 Tom Nairn, The Break-Up of Britain (London: New Left Book, 1977).

${ }^{10}$ William Beer, The Unexpected Rebellion. Ethnic Activism in Contemporary France (NewYork: New York, Univ. Pr., 1980).

${ }^{11}$ Michael Hechter, Internal Colonialism. The Celtic Fringe in British National Development, 1536-1966 (London: Routledge and Kegan Paul, 1975).

${ }^{12}$ Peter Gourevitch, "The Emergence of Peripheral Nationalism: Some Comparative Speculations of Political Leadership and Economic Growth", The Comparative Study Nationalism and History 21 (1979), p. 302-322.

${ }^{13}$ Stein Rokkan and Derek Urwin, Center-periphery Structures in Europe (Frankfurt: Campus-Verlag, 1987); Stein Rokkan and Derek Urwin ed., The Politics of Territorial Identity (London: Sage, 1982). 
${ }^{14}$ Paul R. Brass, Ethnicity and Nationalism (New Dehli: Sage, 1991).

${ }^{15}$ Brass (1991), p. 25.

${ }^{16}$ Sidney Tarrow, Struggle, Politics and Reform: Collective Action, Social Movements and Cycles of Protest (Ithaca: Center for Intern. Studies, Cornell Univ., 1989); Rokkan and Urwin (1983).

${ }^{17}$ For a detailed analysis, see B. Chapman, Introduction to French Local Government (London: Allen \& Unwin, 1978); Michel Crozier, La Societé Bloquée (Paris: Ed. du Seuil, 1979); Pierre Grémion, Le Pouvoir Peripherique (Paris: Ed. du Seuil, 1976). An excellent investigation of the clan structure is provided by Jean Louis Briquet, La Tradition en Mouvement. Clientélisme et Politique en Corse (Paris: Belin, 1997).

${ }^{18}$ Jack Hayward, Governing France: The One and Indivisible Republic (London: Weidenfeld and Nicolson, 1983), p.24.

${ }^{19}$ Grémion (1976).

${ }^{20}$ For the formation and evolution of the Canadian federation, see Richard Simeon and Ian Robinson, State, Society and the Development of Canadian Federalism (Toronto: Univ. of Toronto Press, 1990); Arthur I. Silver, The French-Canadian Idea of Confederation, 1964-1900 (Toronto: University of Toronto Press, 1997) and M. Burgess ed., Canadian Federalism: Past, Present, and Future (Leicester: Leicester Univ. Pr.1990).

${ }^{21}$ Elenore Kofman, "Differential Modernisation, Social Conflict and EthnoRegionalism in Corsica", Ethnic and Racial Studies 5, 3, (1982), p.300-312.

${ }^{22}$ See Peter Savigear, "Corsica and the French State", Nations Without a State, ed. C.R. Foster (New York: 1980), p.116-135; Wanda Dressler-Holohan, "Le Mouvement Social Corse. Evolutions et Paradigms", Peuples Mediteraneens 39/39, (1987), p. 301336.

${ }^{23}$ Vanina, Corse. La Liberté, Pas la Mort (Le Mans: 1983), p. 53ff.

${ }^{24}$.D. Chatelain and P. Tafani, Qu 'est-ce qui Fait Courir les Autonomistes? (Paris: 1976), p. $78 \mathrm{ff}$.

${ }^{25}$ For latest dates and evolutions, see Molas, (2001).

${ }^{26}$ Dale Thomson, Jean Lesage and the Quite Revolution (Toronto: Macmillan, 1986); Vincent Lemieux, Le Parti Libéral du Québec (Sainte-Foy: Les Presses de 1'Université Laval, 1993).

${ }^{27}$ See Lemieux (1993).

${ }^{28}$ For a detailed discussion on the middle class approach, see McRoberts (1993) and Coleman (1984).

${ }^{29}$ For an overview, see Fitzmaurice (1995)

${ }^{30}$ See René Lévesque, Option Québec (Montreal: Édition de 1'Homme, 1968).

${ }^{31}$ See for the data: Maurice Pinard, "Les Quatre Phases du Mouvement Indépendantistes Québécois", Un Combat Inachevé, ed. Maurice Pinard, Robert Bernier and Vincent Lemieux (Sainte-Foy: Presses de l'Univ. du Québec, 1970), p. 29-50.

${ }^{32}$ For this problem, see Christian Lammert, "Referendum-Neverendum: Nationalismus und öffentliche Meinung in Quebec, Staat, Nation, Demokratie". Traditionen und Perspektiven moderner Gesellschaften, ed. Marcus Gräser, Christian Lammert and Söhnke Schreyer (Göttingen: 2001), p. 60-76. 
${ }^{33}$ See Pinard (1970), p.49f.

${ }^{34}$ For this argument see Alain Cairns: "The Government and Societies of Canadian Federalism", in: Olling and Westmacott Hg. (1988), p. 103-121.

${ }^{35}$ Corry: "Constitutional Trends and Federalism", in Evolving Canadian Federalism, ed. A.R.M. Lower, F. R. Scott, et al. (Duke University Press, 1958), S. 101.

${ }^{36}$ Cairns: (1988), p. 107.

${ }^{37}$ Brass (1991), p. 8. 